НАУКОВИЙ ВІСНИК

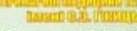

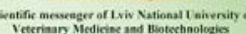

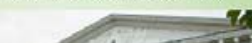

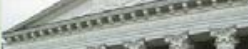

in if Toм 21 Nig 90

2019
Науковий вісник Дьвівського національного університету ветеринарної медицини та біотехнологій імені С.3. Гжицького. Серія: Сільськогосподарські науки

\author{
Scientific Messenger of Lviv National University
} of Veterinary Medicine and Biotechnologies.

Series: Agricultural sciences

UDC 636.2: 636.088:636.083

\title{
Intensity of growth of calves of Ukrainian black-and-white dairy breed in colostrum and milk periods while feeding them with pyridoxine hydrochloride
}

\author{
O.V. Yaremko, R.A. Peleno
}

Stepan Gzhytskyi National University of Veterinary Medicine and Biotechnologies Lviv, Ukraine

Article info

Received 18.02.2019

Received in revised form 19.03.2019

Accepted 20.03.2019

Stepan Gzhytskyi National University of Veterinary Medicine and Biotechnologies Lviv, Pekarska Str., 50, Lviv, 79010, Ukraine.

Tel.: +38-096-820-65-91 E-mail:olhaja@ukr.net
Yaremko, O.V., \& Peleno, R.A. (2019). Intensity of growth of calves of Ukrainian black-and-white dairy breed in colostrum and milk periods while feeding them with pyridoxine hydrochloride. Scientific Messenger of Lviv National University of Veterinary Medicine and Biotechnologies. Series: Agricultural sciences, 21(90), 108-112. doi: 10.32718/nvlvet-a9019

The effect of pyridoxine hydrochloride on the body mass of animals, absolute and average daily increment, relative growth rate, growth factor of live weight and multiplicity of increase in live weight of calves in the early stages of postnatal ontogenesis were studied. For the experiment, six groups of one-day calves (control and five experimental) were formed, with 5 animals in each, which, in addition to the main diet (MD), fed pyridoxine hydrochloride in different doses, according to the scheme: control group - MD, I experimental group - MD $+1 \mathrm{mg} / \mathrm{kg} \mathrm{g} . \mathrm{m}$ pyridoxine hydrochloride, $I I-M D+2 \mathrm{mg} / \mathrm{kg} g . \mathrm{m}$ of the preparation, III $-M D+3 \mathrm{mg} / \mathrm{kg}$ of $w . \mathrm{m} ., \mathrm{IV}-\mathrm{MD}+4 \mathrm{mg} / \mathrm{kg} \mathrm{g} . \mathrm{m}$ and V experimental group $-\mathrm{MD}+5 \mathrm{mg} / \mathrm{kg} \mathrm{g}$. $m$ pyridoxine hydrochloride. Conditionally, the research was divided into four periods: colostrum - from birth and up to 5 days, until the formation of digestion - from 5 to 21 days, the period of the formation of digestion scar - from 21 to 60 days and the end of the milk period - from 60 to 90 days. It was established that feeding to calves with pyridoxine hydrochloride resulted in an increase in the live weight of 60 days of calves by $5.9 \%$ in the second group $(P<0.05)$, by $8.7 \%$ in the third group, by $8.3 \%$ in $\mathrm{IV}$ and $9.2 \%$ in $V$ groups $(P<0.001)$ and for 90 days it was higher by $9.3 \%, 9.1 \%, 9.2 \%$ and $9.1 \%$ respectively $(P<0.05)$. The highest average daily increments were in the colostrum period in calves $I V$ and $V$ groups, which were added to the main diet, respectively, 4 and $5 \mathrm{mg} / \mathrm{kg} \mathrm{b.w.} \mathrm{pyridoxine} \mathrm{hydrochloride,} \mathrm{in} \mathrm{the} \mathrm{period} \mathrm{prior} \mathrm{to} \mathrm{the}$ formation of digestion scar in calves of group $I V$, in the period of the formation of digestion scar in calves of the III group and at the end of the milking period in calves of group V. Absolute incresements of calves in the colostrum period and the period prior to the formation of digestion scar were the highest in calves of Group IV and the difference in control was respectively 0.34 and $1.05 \mathrm{~kg}$. During the period of the digestion scar formation and the end of the milk period, the highest absolute increases were in calves of group $V$, which was added to the main ration of $5 \mathrm{mg} / \mathrm{kg} \mathrm{b.w.} \mathrm{pyridoxine} \mathrm{hydrochloride.} \mathrm{The} \mathrm{highest} \mathrm{increase} \mathrm{in} \mathrm{body}$ weight of calves in colostric period and prior to the operation scar rate was in group $I V$, the period of digestion scar formation was in the third group and during the completion period of milk in the second group of calves. In colostric period the increase of live weight was higher in calves III, IV and V groups of 5 to 21 days in calves of group IV, from 21 to 60 days in the third group and during the completion period of milk in the second group of calves.

Key words: calves, pyridoxine hydrochloride, live weight, absolute increment, average daily gain, multiplicity of increase in live weight, relative growth rate, coefficients of growth of live weight.

\section{Інтенсивність росту телят української чорно-рябої молочної породи у молозивний і молочний періоди за згодовування їм піридоксину гідрохлориду}

\author{
О.В. Яремко, Р.А. Пеленьо
}

Львівський національний університет ветеринарної медицини та біотехнологій імені С.3. Гжицького, м. Львів, Украӥна 
Вивчали вплив згодовування телятам піридоксину гідрохлориду на масу тіла тварин, абсолютний $і$ середньодобовий прирости, відносну швидкість росту, коефіцієнт приросту живої маси і кратність збільшення живої маси телят на ранніх етапах постнатального онтогенезу. Для проведення досліду було сформовано шість груп однодобових телят (контрольна і п'ять дослідних), по 5 тварин у кожній. Телятам дослідних груп крім основного ращіону (OP) згодовували піридоксин гідрохлорид в різних дозах, а саме: I дослідна група - OP +1 мг/кг ж. м. піридоксину гідрохлориду, II - OP +2 мг/кг ж. м. препарату, III - ОР +3 мг/кг ж. м., IV - ОР +4 мг/кг ж. м. $i$ V дослідна група - ОР + 5 мг/кг ж. м. піридоксину гідрохлориду. Умовно період дослідження був поділений на чотири періоди: молозивний - від народження $і$ до 5 доби, період до становлення рубиевого травлення - від 5 до 21 доби, період становлення рубиевого травлення - від 21 до 60 доби і завершення молочного періоду - від 60 до 90 доби. Встановлено, щзо згодовування телятам піридоксину гідрохлориду привело до зростання, порівняно із контролем, живої маси на б0 добу життя телят на 5,9\% у II групі (P < 0,05), на 8,7\% у III групі, на 8,3\% у IV і на 9,2\% у V групі $(P<0,001)$. На 90 добу різниця живої маси виявилася вищою відповідно на 9,3\%, 9,1\%, 9,2\% і на 9,1\% (P < 0,05). Найвищі середньодобові прирости у молозивний період були у телят IV V груп, яким до основного раціону додавали відповідно 4 і 5 мг/кг ж. м. піридоксину гідрохлориду, у період до становлення рубцевого травлення - у телят IV групи, у період становлення рубиевого травлення - у телят III групи і на завершення молочного періоду - у телят V групи. Абсолютні прирости телят у молозивний період і період до становлення рубцевого травлення виявилися найвишиими у телят IV групи і різниця до контролю становила відповідно 0,34 i 1,05 кг. $У$ період становлення рубцевого травлення $i$ завершення молочного періоду найвищі абсолютні прирости були у телят V групи, яким до основного раціону додавали 5 мг/кг ж. м. піридоксину гідрохлориду. Найвищим у молозивний період і у період до функціонування рубця коефіцієнт приросту живої маси був у телят IV групи, у період становлення рубцевого травлення - у III групі і в період завершення молочного періоду - у телят II групи. У молозивний період кратність збільшення живої маси була найвищою у телят III, IV $i$ V груп, з 5 по 21 добу - у телят IV групи, з 21 по 60 добу - у III групі і період завершення молочного періоду - у II групі телят.

Ключові слова: телята, піридоксин гідрохлорид, жива маса, абсолютний приріст, середньодобовий приріст, кратність збільшення живої маси, відносна швидкість росту, коефіцієнти приросту живої маси.

\section{Вступ}

Ріст тварин є одним із проявів їхнього розвитку. Дослідженнями вчених доведено, що найбільший вплив на ріст і розвиток новонароджених має годівля ïх матерів під час внутрішньоутробного розвитку плоду (Kosheleva, 2003; Protsenko, 2004; Kostenko, 2012; Rozdobudko, 2013; Denkovich et al., 2017). Разом 3 цим відомо, що індивідуальний розвиток організму протікає нерівномірно і відображає сукупність змін, що проходять в клітинах з віком, органах і у всьому організмі за впливу спадковості та постійної взаємодії організму з навколишнім середовищем (Hopka et al., 2007; Zemljanuhina, 2010; Chumachenko et al., 2010; Humennyi et al., 2015; Gordiychuk et al., 2016; 2017). Під час індивідуального розвитку тварини відбуваються вікові морфологічні, біохімічні та фізіологічні зміни, що протікають з різною інтенсивністю. Високим генетичним потенціалом продуктивності, доброю пристосованістю до умов утримання і експлуатації, стійкістю до захворювань та дії паратипових факторів, придатністю для інтенсивних технологій виробництва молока вирізняються тварини української чорно-рябої молочної породи (Zhmur et al., 2004; Kostiuk et al., 2006; Hopka et al., 2007; Shcherbatiuk, 2008). У конкретних кормових i природнокліматичних умовах вони відзначаються хорошими показниками росту і розвитку, проте актуальними для науковців і спеціалістів господарств залишаються питання дії екзогенного піридоксину, який необхідний для молодняку саме у молозивний і молочний періоди (Derevianko et al., 2004; Hopka et al., 2007).

Метою роботи було дослідити вплив згодовування різних доз піридоксину гідрохлориду телятам української чорно-рябої молочної породи у молозивний і молочний періоди на інтенсивність їхнього росту. Для досягнення поставленої мети треба було визначити масу тіла тварин, абсолютний і середньодобовий прирости, відносну швидкість росту, коефіцієнт приросту живої маси і кратність збільшення живої маси за дії різних доз піридоксину гідрохлориду.

\section{Матеріал і методи досліджень}

Для проведення досліду було сформовано шість груп однодобових телят (контрольна і п'ять дослідних), по 5 тварин у кожній. Телятам дослідних груп крім основного раціону (ОР), згодовували піридоксин гідрохлорид в різних дозах, зокрема: I дослідна група - ОР +1 мг/кг ж. м. піридоксину гідрохлориду, II $\mathrm{OP}+2$ мг/кг ж. м. препарату, III - OP + 3 мг/кг ж. м., $\mathrm{IV}-\mathrm{OP}+4$ мг/кг ж. м. i V дослідна група - OP + 5 мг/кг ж. м. піридоксину гідрохлориду. Впродовж досліду (від 1 до 90 доби) тварини контрольної та дослідних груп перебували в однакових умовах годівлі, догляду та утримання, а їх раціони були збалансовані згідно з нормами годівлі молодняку молочного періоду вирощування (Kalashnikov et al., 1985).

Умовно дослід був поділений на чотири періоди: молозивний - від народження і до 5 доби, період до становлення рубцевого травлення - від 6 до 21 доби, період становлення рубцевого травлення - від 22 до 60 доби і завершення молочного періоду - від 61 до 90 доби.

Облік росту худоби проводили шляхом визначення маси тіла, абсолютного і середньодобового приросту, кратності збільшення живої маси, відносної швидкості росту і коефіцієнта приросту живої маси за загальноприйнятими методами (Busenko, 2005).

\section{Результати та їх обговорення}

Встановлено (табл. 1), що в процесі постнатального онтогенезу телят зростала їхня жива маса, проте вірогідних змін, порівняно з контролем, вона зазнала на 60 і 90 доби досліду у II, III, IV i V групах тварин, яким згодовували піридоксин гідрохлорид. На 60 добу життя жива маса телят, порівняно із контролем, була вищою на 5,9\% у II групі (P < 0,05), на 8,7\% у III групі, на $8,3 \%$ у IV i на $9,2 \%$ у V групах (P $<0,001)$, а на 90 добу досліду різниця виявилася вищою відповідно на $9,3 \%, 9,1,9,2$ і на $9,1 \%(\mathrm{P}<0,05)$. 
Таблиця 1

Жива маса телят молозивного і молочного періоду вирощування за дії піридоксину гідрохлориду, кг $(\mathrm{M} \pm \mathrm{m}, \mathrm{n}=5)$

\begin{tabular}{cccccc}
\hline \multirow{2}{*}{ Групи } & \multicolumn{5}{c}{ Доби досліджень } \\
\cline { 2 - 6 } & 1 & 5 & 21 & 60 & 90 \\
\hline K & $26,4 \pm 1,06$ & $28,1 \pm 0,72$ & $33,5 \pm 0,83$ & $54,2 \pm 0,92$ & $71,8 \pm 1,29$ \\
I & $26,8 \pm 1,17$ & $28,6 \pm 1,12$ & $34,1 \pm 1,14$ & $56,2 \pm 1,01$ & $74,5 \pm 1,13$ \\
II & $27,4 \pm 1,03$ & $29,3 \pm 1,25$ & $35,1 \pm 1,18$ & $57,4 \pm 1,12^{*}$ & $77,4 \pm 1,31^{*}$ \\
III & $26,7 \pm 1,05$ & $28,8 \pm 1,32$ & $34,8 \pm 1,07$ & $58,9 \pm 0,81^{* *}$ & $78,9 \pm 1,69^{*}$ \\
IV & $26,6 \pm 0,97$ & $28,7 \pm 1,06$ & $35,1 \pm 0,93$ & $58,7 \pm 0,50^{* *}$ & $78,3 \pm 1,62^{*}$ \\
V & $27,2 \pm 1,12$ & $29,2 \pm 1,14$ & $35,5 \pm 0,96$ & $59,2 \pm 0,96^{* *}$ & $79,2 \pm 1,85^{*}$ \\
\hline
\end{tabular}

Суттєвих змін за дії піридоксину гідрохлориду зазнали і середньодобові прирости телят (рис. 1). У молозивний період вони виявилися вищими, порівняно із контрольною групою, на 12 г у I групі, 30 г у II, 48 г у III, і на 58 г у IV i V групах. У період до становлення рубцевого травлення різниця з контролем становила відповідно 9,4, 27,5, 45, 65,7 і 54,4 г. У період становлення рубцевого травлення різниця 3 контролем становила відповідно 32, 38,9, 83,8, 72,5 і 75,6 г. На завершення молочного періоду середньодобові прирости, порівняно із контрольною групою, виявилися вищими на 26 г у I групі, 80 г у II, 81,6 г у III, i на 68 г у IV і на 83,3 г уV групі. Найвищі середньодобові прирости були у молозивний період у телят IV i V груп, яким до основного раціону додавали відповідно 4 і 5 мг/кг ж. м. піридоксину гідрохлориду, у період до становлення рубцевого травлення у телят IV групи, у період становлення рубцевого травлення у телят III групи і на завершення молочного періоду - у телят V групи.

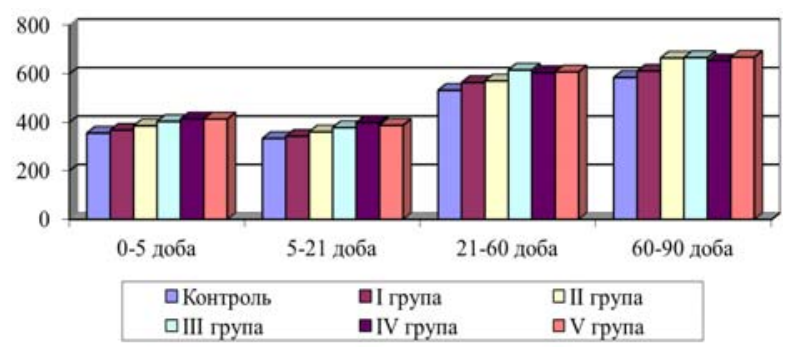

Рис. 1. Середньодобовий приріст телят за дії піридоксину гідрохлориду, г

За дії піридоксину гідрохлориду зросли і абсолютні прирости телят (табл. 2).

Таблиця 2

Абсолютний приріст телят за дії піридоксину гідрохлориду, кг (M \pm m, n = 5)

\begin{tabular}{ccccc}
\hline \multirow{2}{*}{ Групи } & \multicolumn{4}{c}{ Віковий період, доби } \\
\cline { 2 - 5 } & $0-5$ & $5-21$ & $21-60$ & $60-90$ \\
\hline K & $1,78 \pm 0,07$ & $5,34 \pm 0,14$ & $20,77 \pm 1,05$ & $17,57 \pm 0,99$ \\
I & $1,84 \pm 0,05$ & $5,49 \pm 0,18$ & $22,02 \pm 1,06$ & $18,35 \pm 1,04$ \\
II & $1,93 \pm 0,08$ & $5,78 \pm 0,16$ & $22,29 \pm 1,14$ & $19,97 \pm 0,87^{*}$ \\
III & $2,02 \pm 0,09$ & $6,06 \pm 0,19$ & $24,04 \pm 1,13^{* *}$ & $20,02 \pm 1,17^{*}$ \\
IV & $2,12 \pm 0,12$ & $6,39 \pm 0,18$ & $23,60 \pm 1,27^{* *}$ & $19,61 \pm 1,18^{*}$ \\
V & $2,07 \pm 0,10$ & $6,21 \pm 0,22$ & $23,72 \pm 1,30^{* *}$ & $20,07 \pm 1,09^{*}$ \\
\hline
\end{tabular}

У молозивний період і період до становлення рубцевого травлення вони виявилися найвищими у телят IV групи і різниця 3 контролем становила відповідно 0,34 і 1,05 кг. У період становлення рубцевого травлення і завершення молочного періоду найвищі абсолютні прирости були в телят V групи, яким до основного раціону додавали 5 мг/кг ж. м. піридоксину гідрохлориду.

Враховуючи те, що показник абсолютного приросту в молодих тварин не досить об'єктивно відображає інтенсивність процесів росту (Busenko, 2005), нами було визначено відносну швидкість росту живої маси телят (рис. 2). Встановлено, що у молозивний період і період до становлення рубцевого травлення досліджуваний показник виявився найвищим у IV групі телят, у період становлення рубцевого травлення - у III групі й на завершення молочного періоду найвищі показники швидкості росту були у телят II групи, яким протягом усього досліду кожен день до основ- ного раціону додавали по 2 мг/кг ж. м. піридоксину гідрохлориду.

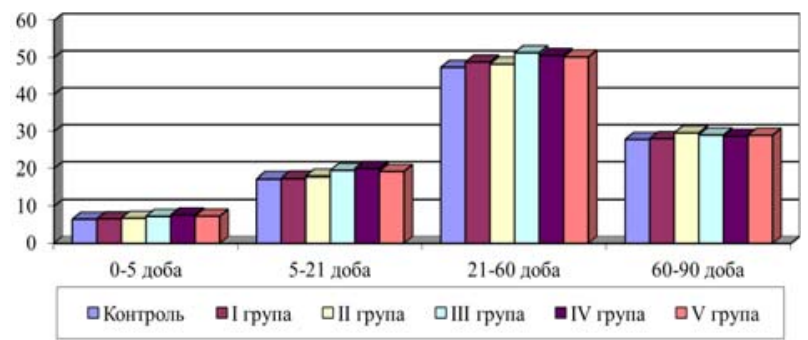

Рис. 2. Відносна швидкість росту живої маси молодняку великої рогатої худоби за дії піридоксину гідрохлориду, \%

Крім змін відносної швидкості росту живої маси молодняку великої рогатої худоби, нами був вирахуваний коефіцієнти приросту живої маси (рис. 3). Най- 
вищим у молозивний період і у період до функціонування рубця він був у телят IV групи, у період становлення рубцевого травлення у III групі і період завершення молочного періоду - в II групі телят.

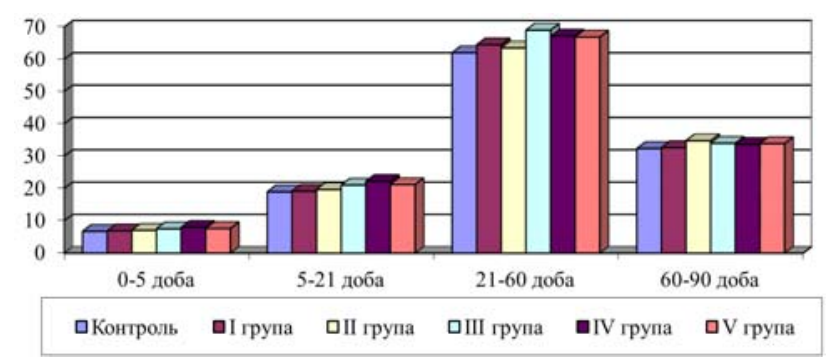

Рис. 3. Коефіцієнти приросту живої маси молодняку великої рогатої худоби за дії піридоксину гідрохлориду, \%

Враховуючи живу масу телят на кінець досліду і живу масу новонароджених тварин, нами було вирахувано кратність збільшення їх живої маси (рис. 4).

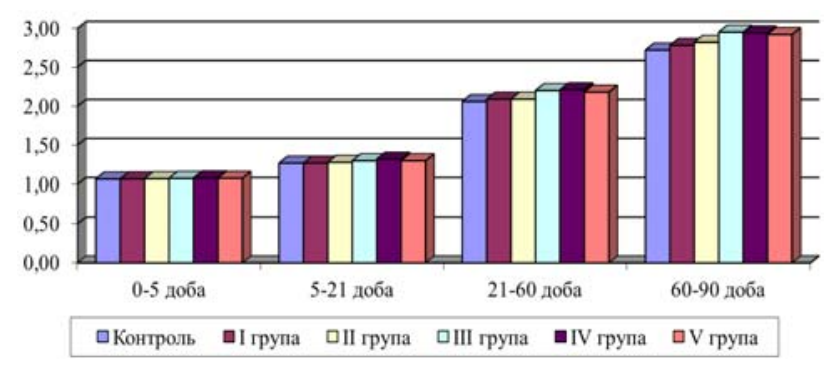

Рис. 4. Кратність збільшення живої маси молодняку великої рогатої худоби за дії піридоксину гідрохлориду, рази

Встановлено, що у молозивний період досліджуваний показник був найвищим у телят III, IV i V груп, з 5 по 21 добу в телят IV групи, з 21 по добу у III групі й період завершення молочного періоду - у II групі телят. Варто зазначити, що за досліджуваним показником телята дослідних груп переважали ровесників контрольних груп і найвищою ця різниця була на завершальному етапі молочного періоду та становила у I групі 1,022 разу, в II - 1,037, у III - 1,085, у IV 1,081 i у V - 1,074 разу.

\section{Висновки}

1. Згодовування телятам піридоксину гідрохлориду привело до зростання, порівняно із контролем, живої маси на 60 добу життя телят на 5,9\% у II групі (P < 0,05), на 8,7\% у III групі, на 8,3\% у IV і на 9,2\% у $\mathrm{V}$ групі $(\mathrm{P}<0,001)$ і на 90 добу відповідно на 9,3\%, 9,1, 9,2 і 9,1\% (P<0,05).

2. Найвищі середньодобові прирости були в молозивний період у телят IV i V груп, яким до основного раціону додавали відповідно 4 і 5 мг/кг ж. м. піридоксину гідрохлориду, в період до становлення рубцевого травлення - у телят IV групи, у період становлення рубцевого травлення - у телят III групи і на завершення молочного періоду - в телят V групи.
3. Абсолютні прирости телят у молозивний період і період до становлення рубцевого травлення виявилися найвищими у телят IV групи, різниця з контролем становила відповідно 0,34 і 1,05 кг. У період становлення рубцевого травлення і завершення молочного періоду найвищі абсолютні прирости були у телят V групи, яким до основного раціону додавали 5 мг/кг ж. м. піридоксину гідрохлориду.

4. Коефіцієнт приросту живої маси найвищим був у молозивний період і в період до початку функціонування рубця в телят IV групи, у період становлення рубцевого травлення у III групі та період завершення молочного періоду у II групі телят.

5. У молозивний період кратність збільшення живої маси була найвищою у телят III, IV i V груп, з 6 по 21 добу у телят IV групи, з 22 по 60 добу у III групі та період завершення молочного періоду - в II групі телят.

Перспективи подальших досліджень. Отримані результати досліджень будуть використані у подальшому вивченні впливу піридоксину гідрохлориду на показники обміну протеїнів та гемопоезу.

\section{References}

Busenko, O.T. (2005). Tekhnolohiia vyrobnytstva produktsii tvarynnytstva. Za red. O.T. Busenka. K.: Vyshcha osvita (in Ukrainian).

Chumachenko, I.P., Mankovskyi, A.Ya., Sryvov, A.I., Koropets, L.A., \& Antoniuk, T.A. (2010). Rekomendatsii z vyroshchuvannia remontnykh telyts molochnoho napriamu produktyvnosti za obmezhenoho vykorystan-nia nezbyranoho moloka. K.: V-vo NUBiP Ukrainy (in Ukrainian).

Denkovich, B.S., Pivtorak, Y.I., \& Gordiychuk, N.M. (2017). Growing heifers for breeding use concentrate "INTERMIKS-calf 30\%". Scientific Messenger LNUVMBT named after S.Z. Gzhytskyj, 19(74), 147151. doi: $10.15421 /$ nvlvet 7433 .

Derevianko, S.V., Diachenko, H.M., Bozhok, L.V., \& Prokopenko, O.I. (2004). Probiotychni preparaty dlia profilaktyky i likuvannia khvorob ta stymuliatsii rostu silskohos-podarskykh tvaryn i ptytsi. Veterynarna medytsyna: Mizhvid. temat. nauk. zb. Kharkiv: IEiKVM UAAN, 84, 819-822 (in Ukrainian).

Gordiychuk, N.M., Denkovich, B.S., \& Gordiychuk, L.M. (2017). The rate of growth calves Simmental depending on the duration of embryogenesis and season of birth. Scientific Messenger LNUVMBT named after S.Z. Gzhytskyj, 19(74), 143-146. doi: 10.15421/nvlvet7432.

Gordiychuk, N.M., Gordiychuk, L.M., Salamakha, I.J. (2016). Behaviourof cows and calves at different ways maintenance. Scientific Messenger LNUVMBT named after S.Z. Gzhytskyj, 18, 2(67), 57-60. doi: 10.15421/nvlvet6713.

Hopka, B.M., Kovalenko, V.P., Melnyk, Yu.F., Naidenko, K.A., Nezhlukchenko, T.I., Pelykh, V.H., Rudyk, I.A., Sakhatskyi, M.I., Trofymenko, O.L., Uhnivenko, A.M., Tsytsiurskyi, L.M., Sheremeta, V.I. (2007). Selektsiia silskohospodarskykh tvaryn. Za zah. red. 
Yu.F. Melnyka, V.P. Kovalenka ta A.M. Uhnivenka. K. (in Ukrainian).

Humennyi, V.D., Humen, V.V., Yemets, O.Iu., \& Ostapenko, A.I. (2015). Molozyvo - ridke zoloto! (porady fakhivtsiam tvarynnytstva). Naukovotekhnichnyi biuleten IT NAAN, 114, 47-57. http://nbuv.gov.ua/UJRN/Ntb_2015_114_10 (in Ukrainian).

Kalashnikov, A.P., Klejmenov, N.I., \& Bakanov, V.N. (1985). Normy i raciony kormlenija sel'skohozjajstvennyh zhivotnyh:cpravochnoe posobie. M.: Agropromizdat (in Russian).

Kosheleva, G.N. (2003). Kormlenie teljat. Zhivotnovodstvo dlja vseh, 3-4, 24-26 (in Russian).

Kostenko, V. (2012). Yakist molozyva ta zdorovia teliaty. Ahrobiznes sohodni, 23, 34-35 (in Ukrainian).

Kostiuk, S.S., Tsymbala, V.I., \& Yaremko, O.V. (2006). Vplyv vitaminu V6 na intensyvnist obminnykh protsesiv i rist bychkiv chorno-riaboi porody. Fiziolohichnyi zhurnal, 52(2), 228 (in Ukrainian).

Protsenko, O. (2004). Rist, rozvytok ta osnovnyi obmin rechovyn telychok zalezhno vid enerhii rostu $\mathrm{v}$ ran- nomu ontohenezi. Tvarynnytstvo Ukrainy, 8, 8-10 (in Ukrainian).

Rozdobudko, T. (2013). Teliatko narodylosia: Miniferma. Hazeta "Silski visti", 13 (18906) (in Ukrainian).

Shcherbatiuk, N.V. (2008). Dynamika pryrostiv zhyvoi masy riznykh linii remontnykh telyts podilskoho zavodskoho typu ukrainskoi chorno-riaboi molochnoi porody. Rozvedennia i henetyka tvaryn. Kyiv: Ahrarna nauka, 345-350 (in Ukrainian).

Zemljanuhina, T.N. (2010). Vlijanie razlichnyh tehnologicheskih priemov vyrashhivanija bychkov $\mathrm{V}$ molochnyj period na ih rost, razvitie i estestvennuju rezistentnost'. Barnaul, 158-160 (in Russian).

Zhmur, A.I., Kos, V.F., \& Muzyka, L.I. (2010). Dynamika zhyvoi masy telyts i koriv riznykh henotypiv ukrainskoi chorno-riaboi molochnoi porody zakhidnoho rehionu Ukrainy. Zb. nauk. prats Bilotserk. derzh. ahrar. un-t. Bila Tserkva, 3(72), 201203 (in Ukrainian). 